\title{
The block to transcription elongation is promoter dependent in normal and Burkitt's lymphoma c-myc alleles
}

\author{
Charlotte A. Spencer, ${ }^{1,5}$ Renee C. LeStrange, ${ }^{2}$ Ulrike Novak, ${ }^{3}$ William S. Hayward, ${ }^{2}$ and Mark \\ Groudine $\mathbf{1}^{1,4}$ \\ ${ }^{1}$ Fred Hutchinson Cancer Research Center, Seattle, Washington 98104 USA; ${ }^{2}$ Memorial Sloan-Kettering Cancer Center, New \\ York, New York 10021 USA; $^{3}$ Department of Medicine, University of Melbourne, Royal Melbourne Hospital, Victoria 3050, \\ Australia; ${ }^{4}$ Department of Radiation Oncology, University of Washington, School of Medicine, Seattle, Washington 98195 USA
}

\begin{abstract}
Aberrant c-myc expression patterns occur in human Burkitt's lymphoma cells, which consistently exhibit c-myc chromosomal translocations, mutations within and flanking the translocated allele, a loss of the block to transcription elongation in exon 1, and a promoter shift to use of the upstream P1 promoter. To define the mechanism responsible for the loss of transcription elongation blockage and resulting c-myc deregulation in Burkitt's lymphoma, we analyzed transcription patterns after transfer of normal and Burkitt's lymphoma c-myc alleles into murine cells and Xenopus oocyte germinal vesicles. We have determined that although the mutations within and surrounding several Burkitt's lymphoma c-myc alleles are not sufficient, in themselves, to abrogate the transcription elongation block, transcription initiation from the P2 promoter may be necessary to obtain the block to transcription elongation. To test directly the role of $\mathrm{c}$-myc promoters in programming transcription elongation blockage, we analyzed transcription patterns from in vitro mutagenized c-myc genes containing deletions of either the P1 or P2 promoter. These data confirm that P1-initiated c-myc transcripts do not terminate at discrete sites near the $3^{\prime}$ end of exon 1, whereas P2-initiated transcripts either terminate or read through the transcription block signals. Therefore, overexpression and/or constitutive expression from the c-myc P1 promoter may contribute to increased readthrough transcription in Burkitt's lymphoma cells and, hence, to aberrant expression patterns or levels of c-myc steady-state transcripts. In addition, the ability of normal cells to modulate c-myc P2-initiated transcription to either read through or to block elongation provides a fine control mechanism over c-myc steady-state RNA levels.
\end{abstract}

[Key Words: c-myc; transcription regulation; block to transcription elongation; Burkitt's lymphoma; gene regulation]

The human c-myc proto-oncogene encodes two phosphorylated nuclear proteins, p64 and p67, which are thought to play an essential role in cellular proliferation and differentiation (Dmitrovsky et al. 1986; Lacy et al. 1986; Yokoyama and Imamoto 1987; Freytag 1988; Hann et al. 1988; Holt et al. 1988; Schweinfest et al. 1988). Several mechanisms have been shown to control the steady-state levels of c-myc mRNA, including the rate of transcription initiation (Nepveu et al. 1987; Lindsten et al. 1988), a block to transcription elongation near the end of c-myc exon 1 (Bentley and Groudine 1986; Eick and Bornkamm 1986; Mechti et al. 1986; Nepveu and Marcu 1986; Lindsten et al. 1988), and stability of the cytoplasmic transcript (Blanchard et al. 1985; Mechti et al. 1986; Nepveu et al. 1987; Lindsten et al. 1988). In several tumor types, rearrangements of the c-myc locus are associated with deregulation of c-myc expression, manifest as differences in c-myc protein

sCorresponding author. and/or mRNA stability, elevated levels and constitutive synthesis of c-myc mRNA, and perturbations of the ratios of the p64 and p67 forms of c-myc protein (Piechaczyk et al. 1985; Cole 1986; Hann et al. 1988).

An example of c-myc deregulation associated with chromosomal translocation is Burkitt's lymphoma, a Bcell malignancy occurring mainly in children and young adults. These tumors are characterized by reciprocal chromosomal translocations of the c-myc gene on chromosome 8 with one of the immunoglobulin loci on chromosomes 2,14 , or 22 . The breakpoints relative to both c-myc and the immunoglobulins vary considerably and may be internal to the c-myc transcription unit or up to several hundred kilobases away (Pellici et al. 1986). Studies of steady-state RNA levels in Burkitt's lymphoma cell lines have established that very low levels of or no detectable c-myc transcripts originate from the nontranslocated c-myc allele (ar-Rushdi et al. 1983; Nishikura et al. 1984; Siebenlist et al. 1984; Taub et al. 1984a; Denny et al. 1985; Nishikura and Murray 1988; Eick and Bornkamm 1989). 
One hypothesis to account for c-myc deregulation associated with Burkitt's lymphoma is a change in the block to transcription elongation near the end of exon 1 (Cesarman et al. 1987). This attenuation-like mechanism, manifest as an excess of exon 1 to intron 1 signal in nuclear runoff assays, was characterized first in retinoic acid-treated HL60 cells (Bentley and Groudine 1986) and later observed in normal human mononuclear cells and Epstein-Barr virus (EBV)-immortalized peripheral blood lymphocytes (PBLs) (Cesarman et al. 1987; Eick et al. 1987). In these cells, the low level of transcription that reads through into exon 2 results in correspondingly low levels of full-length steady-state mRNA. In a recent survey (Cesarman et al. 1987), all Burkitt's lymphoma cell lines that retained the first exon in the translocated $c-m y c$ allele exhibited an increased transcription readthrough in nuclear runoff transcription assays. Such constitutive transcription readthrough could contribute to the higher than normal levels or deregulated expression of $c-m y c$ mRNA in these Burkitt's lymphoma cells. Results of this survey also established that the translocated $c-m y c$ allele contained either a truncated or mutated exon 1 in these Burkitt's lymphomas. These findings led to the hypothesis that alterations to exon 1 in Burkitt's lymphoma c-myc alleles may disrupt transcription blockage signals, leading to constitutive readthrough and, hence, aberrant expression of c-myc steady-state RNA.

One further feature common to Burkitt's lymphoma c-myc alleles that maintain exon 1 is that there is a shift to increased utilization of the minor promoter, Pl (Siebenlist et al. 1984; Taub et al. 1984a,b; Denny et al. 1985; Eick and Bornkamm 1989|. Therefore, it is possible that promoter utilization may be an important determinant of $c-m y c$ expression and/or deregulation in Burkitt's lymphoma.

To define features necessary for deregulated expression of the Burkitt's lymphoma alleles, we analyzed the patterns of transcription from normal and Burkitt's lymphoma c-myc alleles that retain the first exon. We introduced normal Burkitt's lymphoma and in vitro-mutagenized c-myc alleles into both rodent cell lines and Xenopus oocyte germinal vesicles and assayed for transcription elongation blockage and promoter usage. We find that Burkitt's lymphoma c-myc genes, which exhibit constitutive transcription readthrough in their own cell types, are blocked in transcription elongation in exon 1 when introduced into rodent cells or Xenopus oocytes. In addition, Burkitt's lymphoma c-myc transcripts, which initiate predominantly from the P1 promoter within Burkitt's lymphoma cell lines, display predominantly P2 initiation after introduction into rodent cells and Xenopus oocytes. These data suggest that the mutations within and surrounding exon 1 of the Burkitt's lymphoma c-myc alleles studied here are insufficient, in themselves, to effect transcription elongation blockage and that accurate initiation from the P2 promoter may be necessary to program the block to elongation near the end of exon 1. This model was tested by analyzing the transcription patterns from c-myc mu- tants containing deletions of either the P1 or P2 promoters. The results of these analyses confirm that initiation from the P1 promoter leads to readthrough transcription, and that initiation from the P2 promoter is necessary to obtain the block to transcription elongation at the end of $c-m y c$ exon 1.

\section{Results}

Sequence analysis of cloned Burkitt's lymphoma c-myc alleles

The one normal and four Burkitt's lymphoma cell lines analyzed in this study and corresponding cloned c-myc alleles from each are listed in Table 1 and diagrammed in Figure 1. The BN, BL, and BT cell lines were established from tissues from the same Burkitt's lymphoma patient throughout the course of illness (LeStrange 1988). The BN cell line was derived from normal PBLs, immortalized by EBV. The BT and BL cell lines were established from the primary (lung) and relapse (abdominal ascites) tumors, respectively. Both c-myc alleles from the BN line were cloned and sequenced. The sequence matches the published wild-type c-myc sequence /Gazin et al. 1984) throughout the $8.0-\mathrm{kb}$ transcription unit and flanking regions. (LeStrange 1988). The c-myc translocated allele, pLb.13, cloned from the primary tumor, contains $\sim 2 \mathrm{~kb}$ of the $\mathrm{C} \gamma 1$ switch region; the breakpoint occurs at -208 relative to the c-myc P1 promoter. All sequence changes in this allele occur in a 1248 -bp region from the breakpoint to the $5^{\prime}$ half of intron 1 . The protein-coding regions are wild type (LeStrange 1988). Mutations in pLb.13 include a 2-bp deletion between the P1 and $\mathrm{P} 2$ promoters, a 41 -bp deletion in intron 1 , a single base-pair mutation at -198 , and several single base-pair changes within intron 1 (Fig. 1). The c-myc allele, pAb.23, cloned from the relapse tumor, is identical in sequence to pLb.13, except for one additional mutation near the end of exon 1 (LeStrange 1988).

The AW Ramos cell line was derived from an American Burkitt's lymphoma (Wiman et al. 1984). The cloned AW Ramos-translocated allele, pKW4, contains $\sim 2 \mathrm{~kb}$ of the $\mathrm{C} \mu$ switch region with the c-myc breakpoint at -340 relative to the P1 promoter (Table 1, Fig. 1). The pKW4 sequence differs by two single-base substitutions from wild-type $c-m y c$ sequence. One adenine (A)-to-guanine (G) transition occurs at position -158 relative to $\mathrm{P} 1$, and one adenine $(\mathrm{A})$-to-thymine $(\mathrm{T})$ transversion occurs $33 \mathrm{bp}$ upstream of the exon 1/intron 1 boundary. All protein coding sequences are wild type (Wiman et al. 1984).

The KK124 Burkitt's lymphoma cell line is an EBV DNA positive cell line. The translocated c-myc allele, pKK124, cloned from the KK124 cell line, contains $18 \mathrm{~kb}$ of c-myc sequence cloned into $\lambda$ EMBL-3/Table 1; Fig. 1; Denny et al. 1985). The translocation breakpoint lies $>4$ $\mathrm{kb} 3^{\prime}$ to c-myc, and immunoglobulin sequences are not included in this clone. Numerous mutations occur 
Table 1. Normal and Burkitt's lymphoma cell lines and cloned c-myc alleles analyzed in this study

\begin{tabular}{|c|c|c|c|}
\hline Cell line & $\begin{array}{l}\text { Cloned c-myc } \\
\text { allele }\end{array}$ & Description & Reference $^{a}$ \\
\hline $\begin{array}{l}\text { BN } \\
\quad \text { (EBV-immortalized PBLs) }\end{array}$ & pNb.12 & $\begin{array}{l}\text { 8.0-kb HindIII-EcoRI fragment cloned into pUC12. } \\
\text { Sequence is wild type. }\end{array}$ & 1 \\
\hline $\begin{array}{l}\text { BT } \\
\text { (Burkitt's lymphoma, first tumor) }\end{array}$ & pLb. 13 & $\begin{array}{l}\text { 8.0-kb HindIII-EcoRI fragment cloned into pUC12. } \\
\text { Translocated allele } t(8 ; 14) \text {. Contains } 2 \mathrm{~kb} \text { of } \mathrm{C} \gamma 1 \\
\text { switch region. Breakpoint at }-208 . \text { Mutations } \\
\text { in exon } 1 \text { and intron } 1 .\end{array}$ & 1 \\
\hline $\begin{array}{l}\text { BL } \\
\text { (Burkitt's lymphoma, relapse tumor) }\end{array}$ & pAb.23 & $\begin{array}{l}\text { Same as pLb.13, with one additional mutation in } \\
\text { exon } 1 .\end{array}$ & 1 \\
\hline $\begin{array}{l}\text { AW Ramos } \\
\text { (Burkitt's lymphoma) }\end{array}$ & pKW4 & $\begin{array}{l}\text { 7.5-kb EcoRI fragment cloned into pBR322. Trans- } \\
\text { located allele } \mathrm{t}(8 ; 14) \text {. Contains } 2 \mathrm{~kb} \text { of IgM } \\
\text { switch region. Breakpoint at }-340 \text {. Two single- } \\
\text { base-pair mutations in exon } 1 \text { and upstream. }\end{array}$ & 2 \\
\hline $\begin{array}{l}\text { KK124 } \\
\quad \text { (Burkitt's lymphoma) }\end{array}$ & pKK124 & $\begin{array}{l}\text { 18-kb Sall fragment cloned into EMBL-3. Trans- } \\
\text { located allele } t(8 ; 22) . \text { Breakpoint } 4 \mathrm{~kb} 3^{\prime} \text { to c- } \\
\text { myc. Mutations in exon } 1 \text { and flanking. }\end{array}$ & 3 \\
\hline
\end{tabular}

a(1) Lestrange et al. (1988); (2) Wiman et al. (1984); (3) Denny et al. (1985).

within c-myc exon 1 in pKK124 (Denny et al. 1985), including an 8 -bp insertion, $7 \mathrm{bp} 3^{\prime}$ to the $\mathrm{P} 2$ promoter, and a 28 -bp deletion, 125 bp upstream from the exon $1 /$ intron 1 boundary (Fig. 1).

\section{Burkitt's lymphoma cell lines show transcription readthrough}

Nuclear runoff assays (Fig. 2A) were performed on isolated nuclei from the normal $\mathrm{BN}$ line and the Burkitt's lymphoma lines BL, BT, AW Ramos, and KK124. Nascent $\left.{ }^{32} \mathrm{P}\right] \mathrm{UTP}$-labeled RNA from runoff assays was hybridized to excess single-stranded probes slot-blotted onto membranes. The probes detect sense and antisense transcripts from regions of $c-m y c$, indicated in Figure 2D. Runoff transcription of the c-myc gene was sensitive to $2 \mu \mathrm{g} / \mathrm{ml} \alpha$-amanatin, indicating transcription by RNA

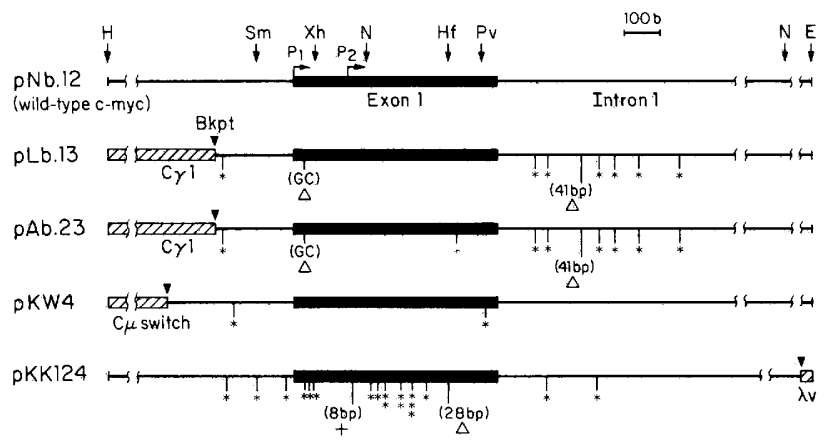

Figure 1. Restriction map and sequence changes in wild-type (pNb.12) and translocated Burkitt's lymphoma c-myc alleles. Shown are exon 1 , intron 1 , and $5^{\prime}$-flanking regions of clones described in Table 1 . All clones contain wild-type sequence for exons 2 and 3. Translocation breakpoints are indicated by solid inverted triangles; immunoglobulin sequences as hatched boxes. $\left({ }^{*}\right)$ Single base-pair mutations; $(\Delta)$ larger deletions; $(+)$ larger inserts. polymerase II (data not shown). An 10-fold excess of exon 1 signal over intron 1 was observed in the transcription analysis of the $\mathrm{BN}$ line, a pattern of $\mathrm{c}-\mathrm{myc}$ transcription typical of normal cells (Bentley and Groudine 1986; Eick et al. 1987). In contrast, an approximately equal exon 1-to-intron 1 signal was observed in the BT, BL, AW Ramos, and KK124 cell lines, a runoff transcription pattern characteristic of Burkitt's lymphoma c-myc genes (Cesarman et al. 1987). The equal exon 1-to-intron 1 signal represents a twofold greater transcription level for exon 1 relative to that of intron 1 because of the lower uridine content for transcripts in the exon 1 probe region ( $73 \mathrm{Us}$ ), compared to transcripts in the intron 1 probe region (136 Us). Hence, after adjustment of the runoff signal ratios that result from the lower uridine content in the exon 1 probe region, the $\mathrm{BN}$ line exhibited an $\sim 20$-fold excess of exon 1 over intron 1 transcription; the $\mathrm{BT}, \mathrm{BL}, \mathrm{AW}$ Ramos, and KK124 lines displayed an approximately twofold excess of exon 1 transcription over that of intron 1 . The lower intensity signal for exon 2 in contrast to intron 1 in these assays is the result of the lower uridine content of transcripts within the exon 2 probe region. After normalization to the runoff signals of the actin and GAPDH genes (data not shown), the BL (relapse tumor) cell line showed a threefold increase in exon 1 signal compared to the $\mathrm{BN}$ and BT exon 1 signals and, hence, an increase in c-myc transcription initiation over the $\mathrm{BN}$ and $\mathrm{BT}$ lines.

To assess the levels of c-myc steady-state mRNA in these normal and Burkitt's lymphoma cell lines, Northern blot analyses of the RNA from BN, BT, and BL cell lines were performed (Fig. 2B). One blot (left) was hybridized to a c-myc exon 3 probe. A duplicate blot (right) was hybridized to an actin probe. After standardization to levels of actin expression, the values indicated 13- and 30-fold more c-myc RNA in the BT and BL lines, respectively, than in $\mathrm{BN}$ cells. Hence, the levels of c-myc RNA in these cell lines reflect a combination of the level of transcription initiation plus the extent to 

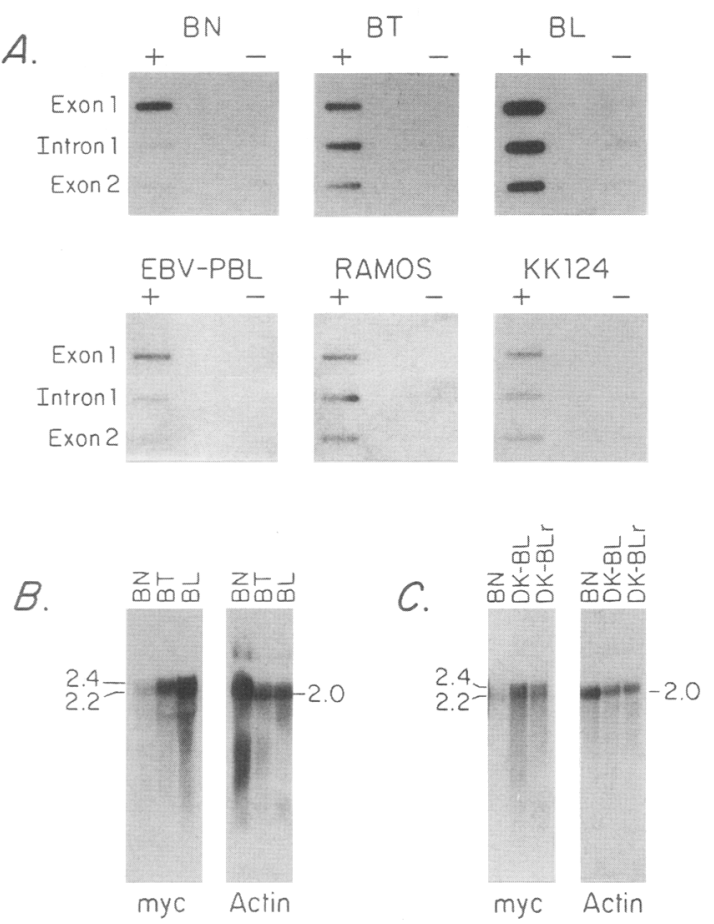

$D$.

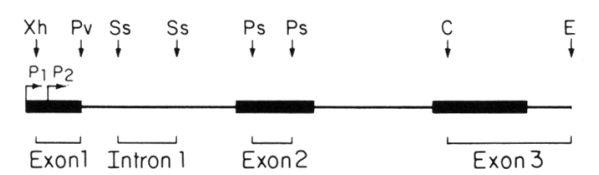

Figure 2. Nuclear runoff transcriptions and Northern blot analyses of c-myc RNA in normal and Burkitt's lymphoma cell lines. (A) [ $\left.{ }^{32} \mathrm{P}\right]$ UTP-labeled nascent RNAs, isolated from nuclei of cell lines BN and EBV-immortalized PBL and Burkitt's lymphoma cell lines BT, BL, AW Ramos, and KK124, were hybridized to an excess of single-stranded M13 probes that detect sense $(+)$ and antisense $(-)$ transcripts corresponding to the restriction fragments diagrammed in $D$. Runoff data on the EBVimmortalized PBLs and AW Ramos cell line confirm previous data (Cesarman et al. 1987). $(B)$ Northern blots of RNA from normal and Burkitt's lymphoma cell lines. Total RNA 127-40 $\mu \mathrm{g}$ ) from BN, BT, and BL cell lines was extracted and analyzed as described in Materials and methods. One blot (left) was hybridized with the human c-myc exon 3 probe shown in $D$. An identical blot (right) was hybridized with an actin probe. RNA sizes are indicated in kilobases. Band intensities were assessed with a scanning densitometer. $(C)$ Northern blot of poly $|A|^{+}$ RNAs from the BN cell line and DK tumors. Poly $\mid A)^{+}$RNA $\mid 1$ $\mu \mathrm{g}$ ) from BN, DK-BL (lung fluid from primary tumor), and DK$\mathrm{BLr}$ (abdominal ascites fluid from relapse tumor) was analyzed as in $B$. $(D)$ Map of c-myc probes used in $A, B$, and $C$. Boxes are exons of human c-myc gene. Runoff probe uridine contents for sense transcripts in each probe region are exon $1,73 \mathrm{U}$; intron 1, $136 \mathrm{U}_{\text {; }}$ and exon 2, $69 \mathrm{U}$. Restriction enzyme sites are (C) ClaI, (E) EcoRI, (Ps) PstI, (Pv) PvuII, (Ss) SstI, and (Xh) XhoI.

which the initiated transcripts read through the block to transcription elongation near the end of $c-m y c$ exon 1.

We also determined the steady-state levels of c-myc RNA in the original tumors from which the BT and BL lines were derived. As seen in Figure $2 \mathrm{C}$, the relative amounts of c-myc RNA in tumors, after standardization for actin expression, were ninefold and sixfold higher in the DK-BT (primary tumor) and DKBLr (relapse tumor), respectively, than in the $\mathrm{BN}$ cell line.

Both the AW Ramos and KK124 lines showed increased readthrough c-myc transcription (Fig. 2A; Cesarman et al. 1987) and elevated levels of steady-state c-myc RNA (Wiman et al. 1984; Denny et al. 1985). Such elevated transcript levels in these lines, as in the BT and $\mathrm{BL}$ lines, could result from increased transcription readthrough to full-length c-myc mRNA compared to the level of readthrough transcription in EBV-immortalized PBL lines (Fig. 2A).

Burkitt's lymphoma c-myc alleles display a block to transcription elongation after transfection into murine cells

To determine whether the sequence changes present in these Burkitt's lymphoma c-myc alleles were sufficient to effect transcriptional readthrough, we transfected both normal (pNb.12) and Burkitt's lymphoma (pLb.13, pAb.23, pKW4 and pKK124) c-myc alleles into the murine pre-B lymphocyte cell line 18-81 (for details of human c-myc clones, see Fig. 1; Table 1). Stable polyclonal and monoclonal cell lines were established from each c-myc construct in 18-81 cells, as described in $\mathrm{Ma}$ terials and methods. Southern blot analysis showed between 1 and 10 unrearranged human c-myc inserts in polyclonal and monoclonal lines $1881 / \mathrm{pNb} .12,18-81 /$ pLb.13, 18-81/pAb.23, 18-81/pKW4, and 18-81/pKK124 (data not shown). A murine pre-B cell line was chosen as a transfection host for several reasons. First, sufficient nucleotide sequence divergence exists between exon 1 and intron 1 of mouse c-myc and exon 1 and intron 1 of human c-myc to permit use of human c-myc probes that do not cross-hybridize with mouse c-myc transcripts in nuclear runoff assays. Second, the mouse c-myc gene exhibits a block to transcription elongation within its exon 1 similar to that of human c-myc. (Nepveu and Marcu 1986; Nepveu et al. 1987; Bentley and Groudine 1988; Wright and Bishop 1989).

Nuclei were isolated from polyclonal and monoclonal lines, and nuclear runoff transcription assays performed (Fig. 3). Nascent [32P]UTP-labeled RNA from runoff transcription assays was hybridized to excess, immobilized single-stranded probes. These probes detect sense and antisense c-myc transcripts for regions shown in Figure 3B. Double-stranded plasmid probes for the housekeeping genes GAPDH and histone $\mathrm{H} 2 \mathrm{~b}$ were included as controls for levels of transcription by RNA polymerase II. Hybridization to the 5S rRNA gene probe served as an indicator of RNA polymerase III transcription levels in the runoff assays. The plasmid probe pGem-1 provided an estimate of transcription occurring within vector sequences. Transcription initiating within vector sequences and reading through into the c-myc gene contributed little to c-myc exon 1 runoff assay signals, as indicated from the low level of hybridization to the $5^{\prime}$ sense strand probe in all cell lines assayed (Fig. 

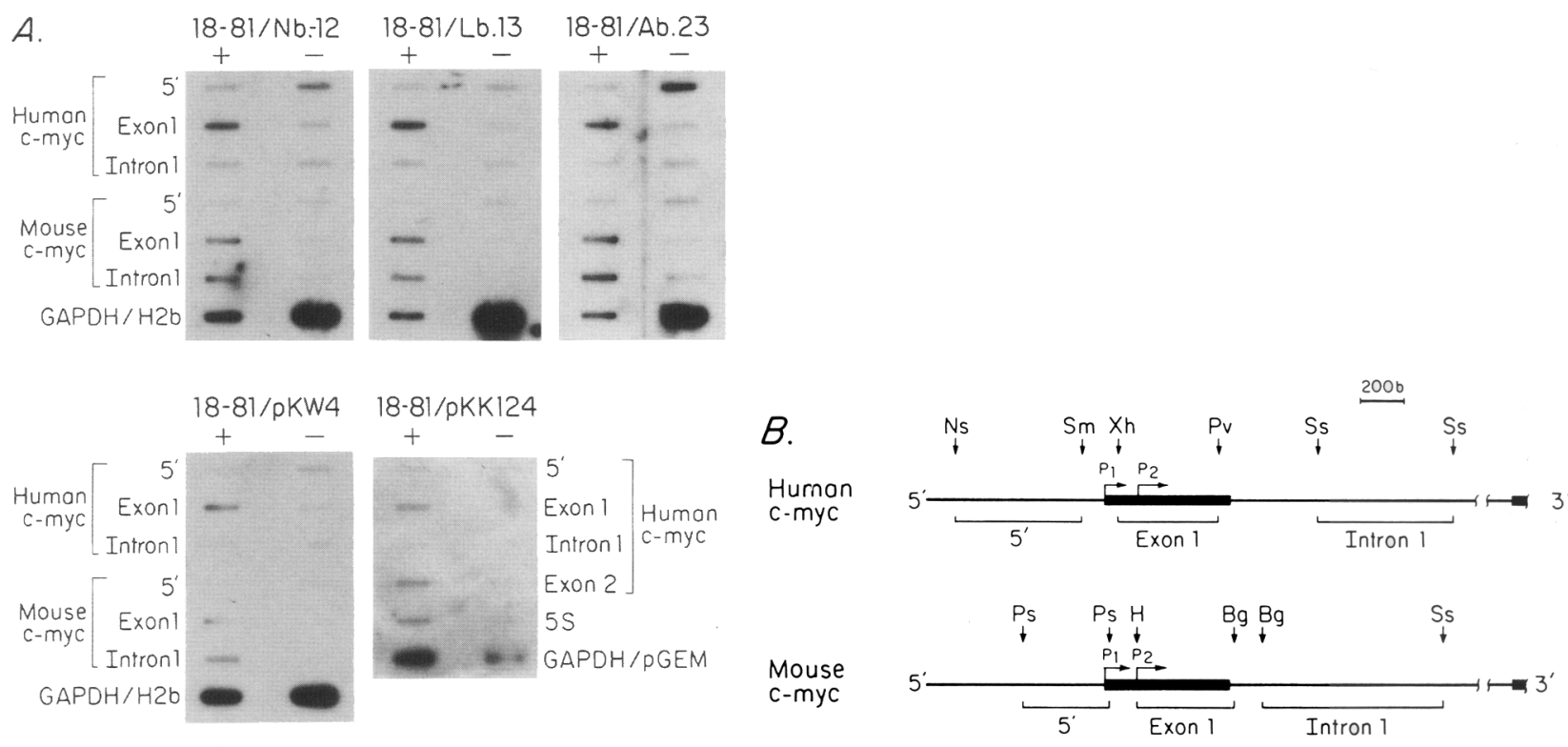

Figure 3. Nuclear runoff transcription assays of mouse 18-81 cell lines transfected with human c-myc alleles. $(A)$ Nuclei were isolated from monoclonal $18-81$ cell lines stably transfected with human c-myc clones pNb.12, pLb.13, pAb.23, pKW4, and pKK124, and runoff transcription assays were performed as described in Materials and methods. Nascent RNA products were purified and hybridized to slot-blotted probes that detect sense $(+)$ and antisense $(-)$ transcripts originating from regions of mouse and human c-myc genes, as diagrammed in $B$. Probes included as controls for RNA polymerase II transcription were chicken GAPDH and histone $\mathrm{H} 2 \mathrm{~b}$. The $5 \mathrm{~S}$ RNA probe was used to assess levels of transcription by RNA polymerase III. Plasmid pGem-1 was included as a probe to detect transcripts originating within vector sequences. Both sense and antisense transcription within the mouse and human c-myc genes was sensitive to $2 \mu \mathrm{g} / \mathrm{ml} \alpha$-amanatin (data not shown). (B) Map of human and mouse c-myc genes and probes used in nuclear runoff assays. Single-stranded M13 probes detecting sense and antisense transcripts from the $5^{\prime}$, exon 1 , and intron 1 regions are shown. Probe uridine contents for sense transcripts in each region are as follows: Human c-myc 5', $121 \mathrm{U}$; exon 1, $73 \mathrm{U}$; intron 1,136 $\mathrm{U}$; mouse c-myc 5', $64 \mathrm{U}$; exon 1, $93 \mathrm{U}$; intron 1, $206 \mathrm{U}$. Transcripts initiating at the mouse P2 promoter and terminating 206 bases downstream, as mapped in Xenopus oocytes (Bentley and Groudine 1988), contain 43 Us. Restriction enzyme sites are (Bg) BglII, (H) HindIII, (Ns) NsiI, (Ps) PstI, (Pv) PvuII, (Ss) SstI, (Sm) SmaI, (Xh) XhoI.

3). Runoff transcription from both human and mouse c-myc genes in $18-81$ cells was sensitive to $2 \mu \mathrm{g} / \mathrm{ml} \alpha$ amanatin, indicating transcription by RNA polymerase II (data not shown). Human c-myc antisense transcription was detected in all transfected cell lines, particularly in the $5^{\prime}$ upstream region. High levels of antisense human c-myc transcription in the $5^{\prime}$ region have been observed previously in HL60 cells before and after differentiation (Bentley and Groudine 1986).

In all cell lines, whether transfected with normal (pNb.12) or Burkitt's lymphoma (pLb.13, pAb.23, pKW4, and $\mathrm{pKK} 124) \mathrm{c}-m y c$ alleles, an approximately fivefold excess of exon 1-to-intron 1 signal from the human c-myc alleles was observed, indicating a strong block to transcription elongation. After adjustment for uridine content of transcripts within probe regions, these lines exhibited an $\sim 10$-fold excess of exon 1-to-intron 1 transcription. Nuclear runoff assay results were identical for both polyclonal and monoclonal lines transfected with each human c-myc allele. Control runoffs using nuclei of nontransfected mouse 18-81 cells showed no detectable hybridization to human sense or antisense probes (data not shown).

Endogenous mouse c-myc transcription was detected with a series of single-stranded probes covering the mouse $5^{\prime}$ (upstream), exon 1 and intron 1 regions (Fig. 3). After adjustment for the number of uridine residues in the mouse exon 1 and intron 1 probes, there was an approximately fourfold excess of mouse exon 1-to-intron 1 transcription in these lines. An excess of mouse exon 1 over intron 1 signal in nuclear runoffs has been observed previously for 18-81 cells (Mechti et al. 1986) and for other murine lymphoid, myeloid, and fibroblast cell lines (Nepveu and Marcu 1986). These results demonstrate that the sequence changes near the end of exon 1 in the Burkitt's lymphoma alleles in this study are not sufficient to permit readthrough transcription in mouse pre-B cells that block transcription elongation of the endogenous mouse $c-m y c$ gene.

Burkitt's lymphoma c-myc alleles display a block to transcription elongation after injection into Xenopus oocytes

It has been shown previously that human c-myc templates can be accurately transcribed after injection into Xenopus oocyte germinal vesicles (Nishikura et al. 1985; Bentley and Groudine 1988) and that transcription is prematurely terminated near the end of exon 1 of wildtype c-myc (Bentley and Groudine 1988). The prema- 
turely terminated c-myc RNAs are stable in oocytes, and these truncated RNAs can be isolated and the $5^{\prime}$ and $3^{\prime}$ ends determined. This system was used to identify sequences necessary to specify premature transcription termination in human c-myc exon 1. Using this assay system, it was determined that a 95-bp region from the HinfI site $(+421)$ to 6 bp $3^{\prime}$ to the PvuII site $(+516)$ in human c-myc exon 1 (Fig. 1) was sufficient to program transcription termination $10-20 \mathrm{bp}$ downstream of this fragment (Bentley and Groudine 1988). Two of the Burkitt's lymphoma c-myc alleles (pAb.23 and pKK124) in this study contain mutations within this $95-b p$ region, and two (pLb.13 and pKW4) do not; however, one mutation within the pKW4 allele lies 7 bp $3^{\prime}$ to the PvuII site (Fig. 1; Wiman et al. 1984). To test whether the sequence changes occurring in Burkitt's lymphoma c-myc alleles are sufficient to effect transcriptional readthrough in Xenopus oocyte germinal vesicles, the normal (pNb.12) and Burkitt's lymphoma (pLb.13, pAb.23, pKW4, pKK124) c-myc alleles were injected into Xenopus oocyte germinal vesicles and premature termination was assayed $24 \mathrm{hr}$ later by Northern blot analysis (Fig. 4). The 2.0-kb RNA in Figure 4 represents full-length spliced c-myc mRNA, and the shorter 400- to 500-base species (indicated with an asterisk) represent RNAs terminating prematurely near the end of exon 1 , as described previously (Bentley and Groudine 1988). These RNA products were absent from uninjected oocytes, were sensitive to $2 \mu \mathrm{g} / \mathrm{ml}$ coinjected $\alpha$-amanatin and were not the products of cleavage of longer transcripts (Bentley and Groudine 1988). Both wild-type and Burkitt's lymphoma c-myc alleles, when transcribed in Xenopus oocytes, yielded similar quantities of the 400 - to 500-base prematurely terminated c-myc RNAs (Fig. 4). The presence of the block to transcription elongation was confirmed in nuclear runoff transcription assays of germinal vesicles isolated after injection of the normal and Burkitt's lymphoma alleles (data not shown). Thus, the mutations within exon 1 of the c-myc Burkitt's lymphoma alleles are insufficient to abrogate the block to transcription elongation when these alleles are expressed either in Xenopus oocytes or in murine pre-B cells.

\section{Burkitt's lymphoma cell lines exhibit promoter shifts}

Because the data above established that the mutations in or near exon 1 in these Burkitt's lymphoma c-myc alleles were not sufficient to program readthrough transcription, we were curious as to whether promoter usage might contribute to the increased readthrough transcription of Burkitt's lymphoma c-myc alleles. In normal cell lines, transcripts initiating at the c-myc P2 promoter account for the majority of c-myc steady-state mRNA, with ratios of $\mathrm{P} 1 / \mathrm{P} 2$-initiated transcript ranging from $1: 5$ (Bentley and Groudine 1986) to $1: 2$ (Taub et al. 1984a; Eick and Bornkamm 1989). All Burkitt's lymphoma cell lines examined to date show a promoter shift to $\mathrm{P} 1$, with ratios of $\mathrm{P} 1 / \mathrm{P} 2$-initiated transcripts between $1: 1$ and $4: 1$. (Taub et al. 1984a,b; Denny et al. 1985; Nishikura et al. 1985; Eick et al. 1988; Eick and Born-

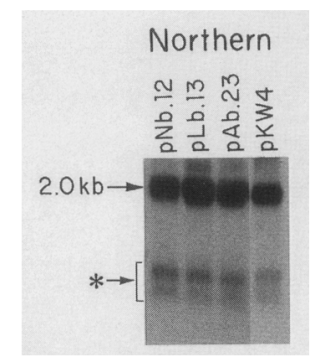

Figure 4. Northern blot of RNA from Xenopus oocytes injected with wild-type and Burkitt's lymphoma c-myc templates. Two nanograms of c-myc plasmid was injected into Xenopus oocyte nuclei, and RNA was extracted $24 \mathrm{hr}$ later from pools of $\sim 20$ oocytes. RNA from oocytes injected with wildtype human c-myc plasmid pNb.12 and Burkitt's lymphoma c-myc plasmids pLb.13, pAb.23, and pKW4 was analyzed as described in Materials and methods. The $2.0-\mathrm{kb}$ transcript is a full-length spliced human c-myc mRNA; the 400- to 500-base transcripts, $\left(^{*}\right)$ represent prematurely terminated c-myc RNAs, ending at site I near the end of exon 1 and site II at the beginning of intron 1, as described previously (Bentley and Groudine 1988).

kamm 1989). To determine the promoter usage in the normal and Burkitt's lymphoma cell lines, RNase protection and S1 nuclease assays were performed (Fig. 5). RNase protection assays of total RNA from both the HL60 promyelocytic leukemia cell line and from the BN cell line, yielded fragments protected by P1- and P2-initiated RNAs, with a predominance of fragments protected by P2-initiated mRNA (Fig. 5A). Ratios of P1/P2 transcripts in the RNase protection assays were $\sim 1: 10$ for HL60 and $1: 5$ for BN. In contrast, total RNA from the Burkitt's lymphoma cell lines BT and BL contained approximately equal amounts of P1- and P2-initiated transcripts.

The origin of the 405- and 370-base intermediate bands, present in varying degrees in all samples, is not clear; however, these bands were present at the highest levels in samples containing large amounts of P1 transcript and may represent P1-initiated transcripts protected by a uniformly labeled probe cleaved at two discrete sites between P1 and P2. These intermediate bands were not observed in an S1 nuclease analysis of these same RNA samples (data not shown) but were always observed in RNase protection assays. Therefore, it is possible that c-myc RNase protection data for the BT and BL lines under-represent actual transcription starts from the $\mathrm{P} 1$ promoter, resulting in higher $\mathrm{P} 1 / \mathrm{P} 2$ ratios.

S1 nuclease mapping of AW Ramos and KK124 RNAs revealed ratios of $\mathrm{P} 1 / \mathrm{P} 2$-initiated transcripts of $\sim 2: 1$ and $4: 1$, respectively, and an apparent shift in P2-initiation site in RNA from the KK124 line (Fig. 5B; Denny et al. 1985). In summary, c-myc RNAs from normal EBVimmortalized PBLs and HL60 cells contain a predominance of P2-initiated transcripts; those from Burkitt's lymphoma cells show an equimolar P1/P2 ratio or predominance of P1-initiated RNA. 


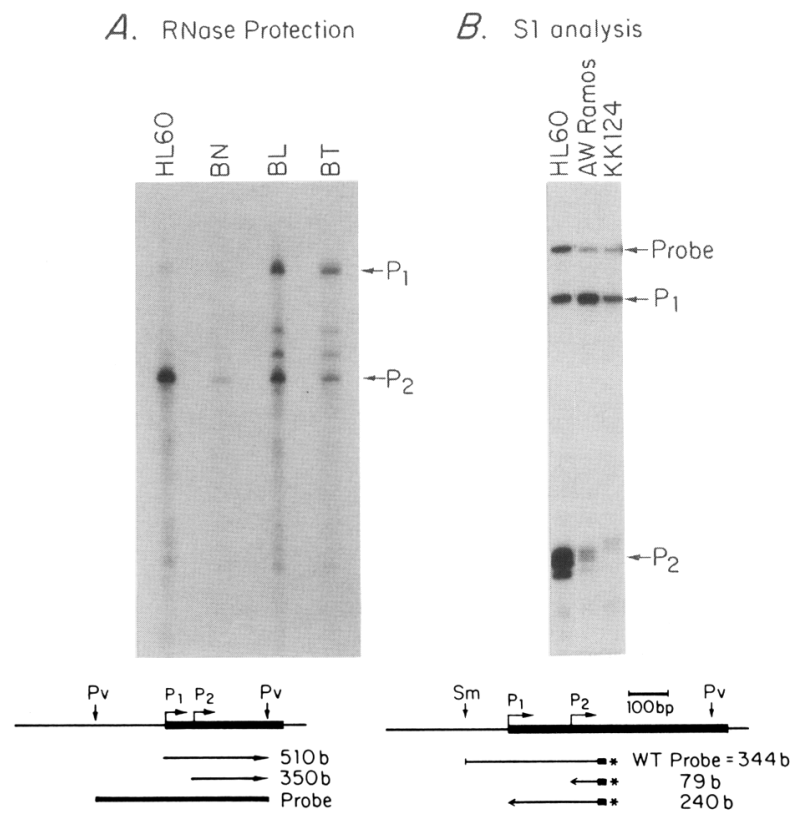

Figure 5. RNase protections and $S 1$ nuclease analyses of normal and Burkitt's lymphoma c-myc steady-state RNAs. $(A)$ Total RNA (8.4 $\mu \mathrm{g}$ of HL60, $20 \mu \mathrm{g}$ of BN, BT, and BL cell lines) was hybridized to the [ ${ }^{32}$ P]UTP-labeled antisense RNA probe diagrammed below. Protected fragments corresponding to RNAs initiating at the $\mathrm{P} 1$ and $\mathrm{P} 2$ promoters are indicated with arrows. Below is a diagram of the c-myc exon 1 region and RNase protection probe. The probe was an 862-base [32P]UTPlabeled antisense RNA extending from the PvuII site of human c-myc at -352 to the PvuII site at +510 . Fragments of 510 and 350 bases are protected by RNAs initiating at the P1 and P2 promoters, respectively. The 2-bp mismatch between the wildtype probe and RNA from the BT and BL cell lines was not recognized by RNase A in these assays, as the estimated 478base protected fragment was not detected. The intermediate bands at 405 and 370 bases may be fragments protected by RNA probe breakdown products. $(B)$ Total RNA $(20 \mu \mathrm{g}$ of HL60 and $40 \mu \mathrm{g}$ of AW Ramos and KK124 cell lines) was hybridized to the 5 '-end-labeled single-stranded DNA probe diagrammed below. Digestions were carried out as described in Materials and methods. Arrows indicate fragments protected by RNAs initiating at the $\mathrm{P} 1$ and $\mathrm{P} 2$ promoters. Below is a diagram of the c-myc promoter region, the 344-base wild-type, single-stranded, end-labeled probe, and fragments protected by RNAs initiating at the $\mathrm{Pl}$ and $\mathrm{P} 2$ promoters.

Burkitt's lymphoma c-myc alleles initiate transcription predominantly from the $P 2$ promoter after transfection into murine cells

The transcription initiation sites of human c-myc RNAs in the transfected mouse 18-81 lines were determined by RNase protection assays (Fig. 6). Two Burkitt's lymphoma-transfected lines yielded sufficient steady-state RNA for assay (a pKW4-transfected line and a pLb.13transfected line). Both show a predominance of P2-initiated $c-m y c$ transcripts, characteristic of c-myc expression in normal cells (Fig. 5; HL60 and BN). As discussed in the previous section, the intermediate bands could be contributed by P1 transcripts protected by cleaved
RNase protection probe. However, the combined signal from the intermediate bands in transfected line RNAs is lower than the P2 signal for each sample, consistent with P2-initiated c-myc transcripts predominating in the 18-81-transfected cell lines. RNA from nontransfected 18-81 cells contributed no protected fragments (data not shown). S1 nuclease analysis of the same RNA samples assayed in Figure 6 confirmed a predominance of P2-initiated human $c-m y c$ transcript in these transfected lines (data not shown). It has been determined previously that transcription initiation occurs predominantly from the mouse c-myc P2 promoter in 18-81 cells (Piechaczyk et al. 1985; Yang et al. 1985). Thus, in contrast to the approximately equimolar ratio of P1 and P2 transcripts in the AW Ramos and BT Burkitt's lymphoma cell lines, there is a predominance of P2-initiated c-myc transcripts in murine cells transfected with cloned alleles from these cell lines and, hence, an association of predominant use of the $\mathrm{P} 2$ promoter with presence of the block to transcription elongation.

Burkitt's lymphoma c-myc alleles initiate transcription predominantly from the P2 promoter after injection into Xenopus oocytes

S1 nuclease protection assays were performed on the same RNA samples analyzed by Northern blot in Figure 4 to determine c-myc promoter usage in Xenopus oocytes injected with normal and Burkitt's lymphoma c-myc alleles (Fig. 7). An approximately fivefold predominance of transcripts initiating from the P2 promoter was observed from both the normal (pNb.12) and Burkitt's lymphoma (pLb.13, pAb.23, pKW4, and pKK124) $\mathrm{c}-\mathrm{myc}$ alleles. Thus, as in the transfection studies in 18-81 cells described above, the block to transcription elongation in the Burkitt's lymphoma c-myc alleles in Xenopus oocytes is associated with a shift from $\mathrm{P} 1$ to $\mathrm{P} 2$ promoter usage.

\section{Transcripts initiating at the P1 promoter exhibit transcription readthrough}

The data presented above provide a correlation between the use of the c-myc P2 promoter and the presence of a block to transcription elongation at the end of exon 1 . To test directly the role of c-myc promoter choice in the block to transcription elongation, deletions of either the P1 or P2 promoters were made in wild-type full-length c-myc clones, and these constructs were tested for transcription patterns after injection into Xenopus oocyte germinal vesicles. The promoter deletion constructs were generated by in vitro mutagenesis and remove the TATA box alone or the region from the TATA box to cap site of either the P1 or P2 promoters.

A northern blot analysis of RNAs transcribed in Xenopus oocytes after injection with wild-type or deleted human c-myc constructs is shown in Figure $8 \mathrm{~A}$. RNA species transcribed from the wild-type, $\Delta \mathrm{P} 1$ (29-bp deletion of P1 TATA box to cap sitel, and $\triangle$ P1TATA 


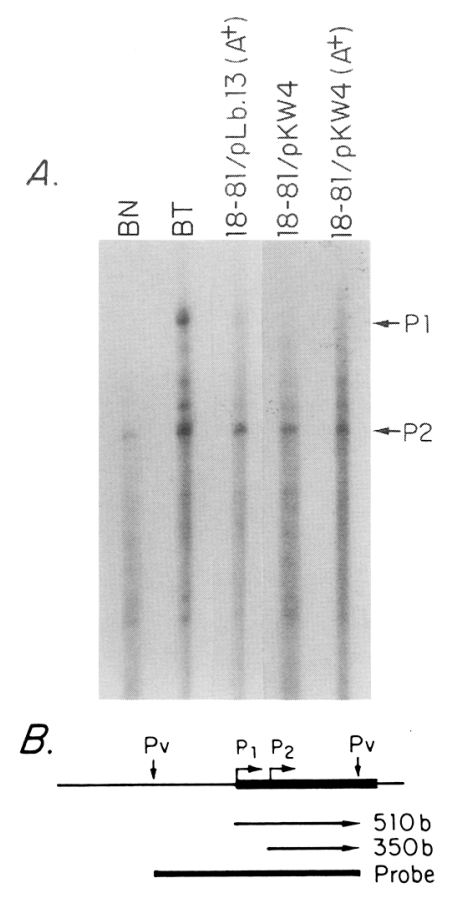

Figure 6. RNase protections of RNA from normal and Burkitt's lymphoma cell lines and from transfected 18-81 cell lines. (A) Total or poly(A) ${ }^{+}$RNA was hybridized to the 862 -base antisense RNA probe shown in $B$, and assays were performed as described in Materials and methods. Protected fragments corresponding to RNAs initiating at the P1 and P2 promoters are indicated with arrows. Total RNA was assayed from the normal B-lymphocyte cell line BN $(20 \mu \mathrm{g})$, the Burkitt's lymphoma cell line BT $(15.6 \mu \mathrm{g})$, and the 18-81 monoclonal cell line transfected with the Burkitt's lymphoma clone pKW4 $(70 \mu \mathrm{g})$. Poly $(\mathrm{A})^{+}$ RNA was assayed from 18-81 monoclonal lines transfected with Burkitt's lymphoma clones pLb.13 (10.7 $\mu \mathrm{g})$ and pKW4 (20 $\mu \mathrm{g}) .(B)$ Diagram of c-myc promoter region with RNase protection probe and protected fragments, as described in Fig. 5.

(6-bp deletion of the P1 TATA box) constructs were both full-length 2.0-kb c-myc RNA and the 400- to 500-base prematurely terminated species. In contrast, transcripts initiating from the $\triangle \mathrm{P} 2$ (31-bp deletion of P2 TATA box to cap site) and $\triangle$ P2TATA (7-bp deletion of P2TATA box) constructs were mostly full-length $(2.0 \mathrm{~kb})$ with little detectable prematurely terminated RNA.

To map the transcription initiation sites from these promoter deletion constructs, S1 nuclease protection assays were performed on the same oocyte RNA samples analyzed by Northern blot in Figure 8A (Fig. 8B). A 505base 3 '-end-labeled $\Delta \mathrm{P} 2 \mathrm{c}-\mathrm{myc}$ probe was hybridized to RNA from oocytes injected with wild-type, $\Delta \mathrm{Pl}$, $\triangle$ P1TATA, $\triangle$ P2, and $\triangle$ P2TATA plasmids, and S1 analysis was performed and interpreted as described in Materials and methods. This probe will protect fragments of 401 bases, corresponding to transcripts initiated at the P1 promoter, and 270 bases, corresponding to transcripts originating from the P2 promoter. S1 analysis of RNA transcribed from the wild-type construct showed the normal pattern of $\mathrm{P} 1$ and $\mathrm{P} 2$ promoter usage, whereas protected fragments from c-myc RNA transcribed from the $\triangle \mathrm{P} 1$ and $\triangle \mathrm{P} 1 T A T A$ constructs indicated transcription initiation solely from the $\mathrm{P} 2$ promoter. The minor bands at the P1 (or above) position in these two samples results from upstream-initiated RNAs protected by the probe up to the point of RNA/probe mismatch. S1 analysis of RNA transcribed from the $\triangle \mathrm{P} 2$ and $\triangle \mathrm{P} 2 \mathrm{TATA}$ constructs revealed a 401-base fragment, protected by RNA initiating from the Pl promoter. No transcripts initiating from the P2 promoter region were detected. Hence, it appears that transcripts initiating at the c-myc P1 promoter do not prematurely terminate at the 3 ' end of exon 1, whereas those initiating at the P2 promoter contribute to the $400-500$ base prematurely terminated RNA species.

Results of the $\mathrm{S} 1$ analyses in Figure 8 also show that levels of P1 transcript do not change from wild-type levels in the $\triangle \mathrm{P} 2$ and $\triangle \mathrm{P} 2 \mathrm{TATA}$ samples, therefore suggesting that transcription initiation from $\mathrm{P} 1$ is not altered by the absence of initiation from P2. In addition, there is an approximate threefold excess of P2 transcripts in the $\triangle \mathrm{Pl}$ and $\triangle \mathrm{P} 1 \mathrm{TATA}$ samples compared to the levels of P1 transcripts in the $\triangle \mathrm{P} 2$ and $\triangle \mathrm{P} 2 \mathrm{TATA}$ samples, which is not reflected in the amounts of $2-\mathrm{kb}$ c-myc RNA in the Northern analysis in Figure 8A. This

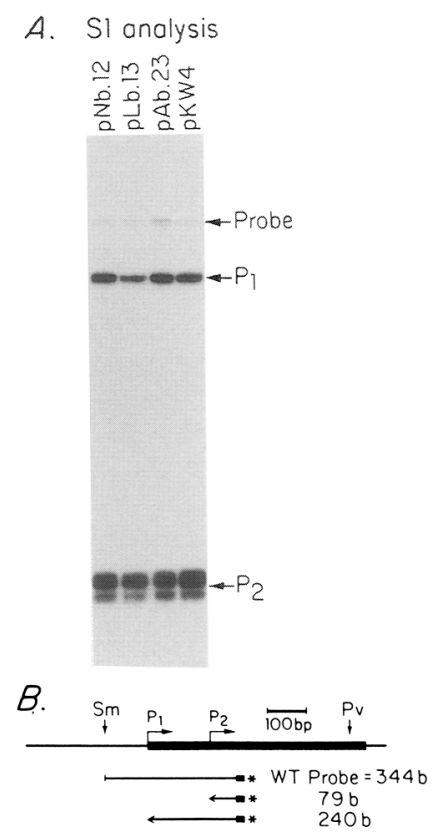

Figure 7. S1 nuclease analysis of RNA from Xenopus oocytes injected with wild-type and Burkitt's lymphoma c-myc templates. (A) The same RNA samples analyzed in Fig. 4 were hybridized to the $5^{\prime}$-end-labeled, purified single-stranded probe diagrammed in $B$, and $S 1$ nuclease digestions were performed as described in Materials and methods. Fragments protected by transcripts initiating at the $\mathrm{P} 1$ and $\mathrm{P} 2$ promoters are indicated by arrows. Full-length probe is protected by RNAs initiating upstream within c-myc or vector sequences. $(B)$ Map of human $c-m y c$ exon 1 region, showing the single-stranded 5 '-end-labeled DNA probe ( 344 bases) and sizes of fragments protected by transcripts initiating at the $\mathrm{P} 1$ and $\mathrm{P} 2$ promoters. 
discrepancy may be attributable, in part, to the quantitative representation in the $S 1$ analysis of the short terminated RNAs originating from the P2 promoter (in the wild-type, $\triangle$ P1 and $\triangle$ P1TATA samples) and the inefficient transfer and under-representation of these small RNAs in the Northern analysis. We are presently addressing further the effects of promoter region deletions on the levels of transcription initiation and elongation from both promoters to examine the possibility of promoter occlusion in the human c-myc gene.

\section{Discussion}

\section{Mutations near the end of exon 1 in Burkitt's lymphoma are insufficient to program transcription readthrough}

We analyzed the sequence changes and transcription patterns of normal and Burkitt's lymphoma c-myc genes to determine the factors leading to deregulated c-myc expression in Burkitt's lymphoma. One consistent feature of the translocated and expressed c-myc allele in Burkitt's lymphoma cells is that exon 1 is either missing or mutated. (Cesarman et al. 1987). In addition, nuclear runoff transcription assays show that the block to transcription elongation near the end of exon 1 is abrogated in Burkitt's lymphoma cells that retain the first exon (Fig. 2; Cesarman et al. 1987). The only exception to the observation of c-myc transcription readthrough in this disease was observed in a slow-growing cell line derived from an AIDS-associated Burkitt's lymphoma (ZajacKaye et al. 1988). Thus, we hypothesized that the sequence changes in the translocated Burkitt's lymphoma c-myc alleles may be within regions essential for programming transcription elongation blockage and, hence, may be responsible for the loss of normal c-myc regulation via this mechanism (Cesarman et al. 1987). Subsequent work from our laboratory, involving transcription analysis of mutated c-myc constructs injected into Xenopus oocyte germinal vesicles, revealed that a 95-bp region extending from the HinfI site $(+421)$ to $6 \mathrm{bp} 3^{\prime}$ of the $P_{\text {VuII }}$ site $(+516)$ in exon 1 was sufficient to program premature transcription termination $10-20$ bp $3^{\prime}$ of this region in Xenopus oocytes when placed downstream of some heterologous promoters (Bentley and Groudine 1988). However, an examination of several sequenced Burkitt's lymphoma c-myc alleles that retain the first exon shows that although many alleles, such as pAb.23, pKK124, and Daudi (Rabbitts et al. 1984), contain mutations in this 95-bp region, others, such as pLb.13, pKW4, JBL2 (Taub et al. 1984b), and BL22 (Taub et al. 1984a), do not. It is apparent, therefore, that sequence changes or factors outside of this 95-bp region must also contribute to the c-myc transcription elongation block in mammalian cells.

In the Burkitt's lymphoma c-myc alleles that lack mutations within the 95-bp region necessary for premature termination of transcription in oocytes, other sequence changes occur within and surrounding exon 1. We addressed whether these sequence changes were suf-

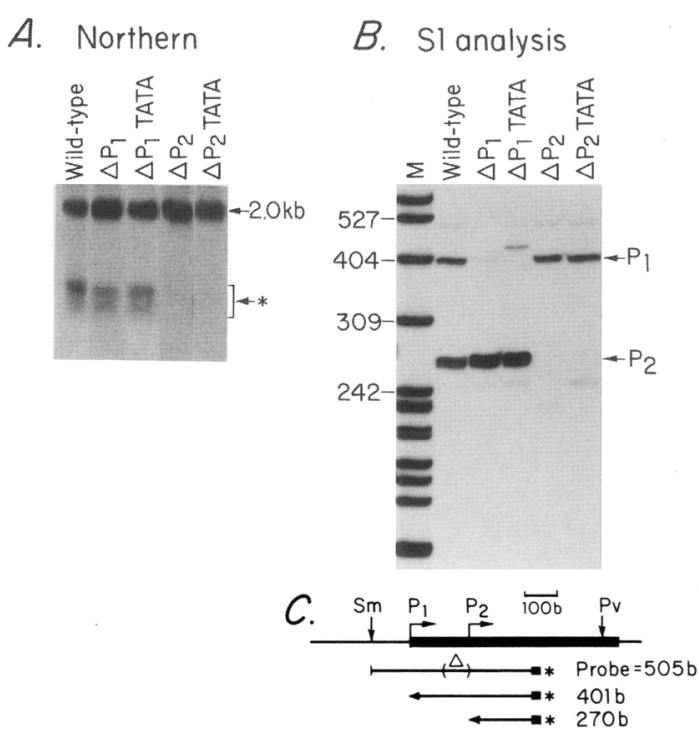

Figure 8. Northern blot and S1 nuclease analyses of RNA from Xenopus oocytes injected with wild-type and in vitro-mutagenized human c-myc templates. Injections and RNA extractions were performed as described in Fig. 4 and Materials and methods. $(A)$ RNA from oocytes injected with wild-type human c-myc plasmid pNb.12 and in vitro-mutagenized c-myc plasmids $\triangle \mathrm{P} 1, \Delta \mathrm{P} 1 T A T A, \Delta \mathrm{P} 2$, and $\triangle \mathrm{P} 2 \mathrm{TATA}$ were analyzed as in Fig. $4 .(B)$ The same RNA samples analyzed in $A$ were hybridized to the 5 '-end-labeled single-stranded DNA probe diagrammed in $C$, and $S 1$ nuclease analysis was performed as described in Materials and methods. Arrows indicate fragments protected by transcripts initiating at the $\mathrm{P} 1$ and $\mathrm{P} 2$ promoters. (C) Map of human c-myc exon 1 region, showing 5'-end-labeled single-stranded probe and sizes of fragments protected by RNAs initiating at the c-myc $\mathrm{P} 1$ and $\mathrm{P} 2$ promoters. The probe contains a 31-base deletion and is homologous to RNA transcribed from the $\triangle \mathrm{P} 2$ construct. Wild-type and $\triangle \mathrm{P} 2 \mathrm{TATA} R \mathrm{R}$ As do not create a cleavable mismatch in the S1 probe, due to looping out of the excess RNA sequences in the probe deletion region. (a) The 5'-end-labeled oligonucleotide used to prime synthesis of the singlestranded antisense DNA probe; $(\Delta)$ deletions. (M) DNA molecular weight markers.

ficient to allow transcriptional readthrough after expression of these alleles in cell types capable of blocking transcription elongation of the wild-type c-myc gene. Our nuclear runoff transcription assays of human c-myc genes expressed in murine pre-B cells (Fig. 3) showed that both normal and Burkitt's lymphoma alleles block transcription elongation, following stable integration into these cells, even though these Burkitt's lymphoma alleles displayed readthrough transcription in their own cell type (Fig. 2). Furthermore, when the Burkitt's lymphoma c-myc alleles were injected into Xenopus oocytes, transcription was terminated prematurely near the end of exon 1, similar to that of wild-type c-myc (Fig. 4). We therefore conclude that mutations within exon 1 and flanking regions of these four Burkitt's lymphoma c-myc alleles are insufficient, in themselves, to account for the loss of c-myc transcription elongation blockage observed in Burkitt's lymphoma cell lines. 
Promoter shifts occur in Burkitt's lymphoma c-myc alleles expressed in heterologous cells

We observed that the ratio of $\mathrm{P} 1 / \mathrm{P} 2$-initiated transcripts was $\sim 1: 5$ in immortalized PBL cell lines and between $\sim 1: 5$ and $1: 10$ in HL60 cells (Fig. 5). These same cell lines showed a block to c-myc transcription elongation in nuclear runoff transcription assays (Fig. 2; Bentley and Groudine 1986). In contrast, Burkitt's lymphoma cell lines BT and BL exhibited a promoter shift to P1/P2 ratios of $\sim 1: 1$ (Fig. 5A). The AW Ramos and KK124 cell lines displayed a more dramatic shift in promoter usage ratio to $2: 1$ and $4: 1$, respectively (Fig. 5; Denny et al. 1985). These Burkitt's lymphoma cell lines also showed a loss of the block to $\mathrm{c}-\mathrm{myc}$ transcription elongation (Fig. 2A).

As described above, although readthrough transcription of Burkitt's lymphoma c-myc alleles was observed in Burkitt's lymphoma cells, the cloned Burkitt's lymphoma c-myc alleles displayed the block to transcription elongation when introduced into the mouse pre- $B$ cell line 18-81 and into Xenopus oocyte germinal vesicles. In addition, transcription from these same Burkitt's lymphoma c-myc alleles showed a shift to a predominance of P2-initiated transcription after transfection into mouse 18-81 cells and injection into Xenopus oocytes. The P1/P2 promoter usage ratios in these Burkitt's lymphoma-transfected lines was $\sim 1: 5$. Hence, the appearance of the block to transcription elongation in normal cells, transfected murine cells, and c-myc-injected Xenopus oocytes is correlated with a predominance of transcription initiation from the c-myc P2 promoter. Previous analysis of human $\mathrm{c}-\mathrm{myc}$ constructs driven from the thymidine kinase and adenovirus major late promoters in Xenopus oocyte germinal vesicles also suggested a promoter-specific contribution to the ability to recognize elongation blockage signals at the end of exon 1 (Bentley and Groudine 1988).

\section{The block to transcription elongation at the end of exon 1 is associated with P2-initiated, but not P1- initiated transcription in Xenopus oocytes}

To test directly the relationship between promoter use and transcription elongation blockage, we created promoter deletion mutants in full-length wild-type human c-myc plasmids and tested these in Xenopus oocyte germinal vesicles for both promoter usage and their ability to direct prematurely terminated transcription at sites near the $3^{\prime}$ end of exon 1 . Both of the deletion constructs that remove P1 promoter elements showed the wildtype pattern of 400 - to 500 -base prematurely terminated transcripts, and $\mathrm{S} 1$ analysis confirmed that all transcripts initiated from the P2 promoter in these constructs. In contrast, the deletion constructs that removed P2 promoter elements did not direct premature transcription termination, and $S 1$ analysis revealed that all transcripts were initiating from the c-myc P1 promoter. Runoff transcription assays of oocyte germinal vesicles injected with these promoter deletion mutants confirmed that a strong block to transcription elonga- tion occurred in transcripts from both the wild-type and P1-deleted constructs in oocytes and that read-through transcription occurred from the P2 promoter-deleted constructs (data not shown). Also, preliminary runoff transcription assays of rodent cells stably transfected with the human c-myc P2 promoter deletion mutants also show a pattern of readthrough transcription, whereas those transfected with human c-myc clones bearing deletion of the P1 promoter elements show the wild-type pattern of block to transcription elongation (C. Spencer and M. Groudine, unpubl.).

Although these data are consistent with the hypothesis that promoter-specific effects modulate transcription elongation blockage, they do not exclude the possibility that the structure of the c-myc RNA could contribute to the ability to terminate or block transcription elongation. P1-initiated transcripts are 161 bases longer than those initiating at P2, and the two transcripts could adopt different internal secondary structures. Also, the P2 promoter deletion constructs, which demonstrated that P1-initiated transcripts do not terminate in Xenopus oocytes, contain small deletions / 31 and $7 \mathrm{bp}$, respectively) that may alter RNA structure, resulting in loss of premature termination or in the degradation of the prematurely terminated transcripts. To test directly the role of $\mathrm{P} 1$ and $\mathrm{P} 2$ promoter position versus integrity on programming transcription elongation blockage, we have created an in vitro-mutagenized human c-myc template that contains a 161-bp deletion extending from the $3^{\prime}$ end of the P1 TATA box through to the $3^{\prime}$ end of the P2 TATA box, therefore replacing the P2 TATA box (and regions upstream) with the P1 TATA box plus upstream sequences and retaining the P2 cap site. Preliminary data on transcription patterns of this mutant construct expressed in Xenopus oocytes indicate that although transcription initiates accurately and abundantly at the P2 cap site, these P2-initiated transcripts now read through (data not shown). These data suggest that RNA structure or sequence alone cannot account for the presence of prematurely terminated transcripts in those initiating from the $\mathrm{P} 2$ promoter. Hence, it seems likely that elements between P1 and P2 promoters, or elements juxtaposed from upstream of the P1 TATA box to the P2 promoter position, contribute to programming premature transcription termination in P2-initiated transcription.

\section{Implications for c-myc regulation in normal and Burkitt's lymphoma alleles}

The observation of a correlation between transcription elongation blockage and predominant use of the P2 promoter in normal and Burkitt's lymphoma cells, together with data from the promoter deletion experiments, suggest that a promoter-specific phenomenon may determine the ability of RNA polymerase II complexes to recognize downstream termination or blockage signals. Several examples of the regulation of transcription termination in prokaryotes and eukaryotes are relevant in considering this hypothesis. For example, transcription 
through the tR1 terminator of bacteriophage $\lambda$ and the subsequent expression of the early genes depends on the association of RNA polymerase with the $\mathrm{N}$ antiterminator protein. This association is established as RNA polymerase traverses the nut site situated downstream of the promoter (Barik et al. 1987; Horwitz et al. 1987). Similarly, the $\lambda \mathrm{Q}$ antiterminator protein associates with RNA polymerase at a site indistinguishable from the $\mathrm{pR}^{\prime}$ late gene promoter, resulting in readthrough at the $t^{\prime}$ downstream terminator (Grayhack et al. 1985). In addition, the eukaryotic U1 and U2 snRNA genes are transcribed by RNA polymerase II, and the $3^{\prime}$ ends are not polyadenylated but are formed by cleavage or termination during transcription. If mRNA promoters, such as adenovirus major late promoter or $\beta$-globin, are substituted for the U1 and U2 promoters, proper 3 ' ends do not form. However, the U1 and U2 promoters are able to substitute for each other (Neuman et al. 1986; Hernandez and Lucito 1988). Thus, the ability to recognize $3^{\prime}$ end signals is determined during initiation, presumably by interaction of RNA polymerase complexes with specific processing or termination factors.

Previous studies have revealed that the c-myc P2 promoter is capable of being modulated with regard to transcription elongation blockage in HL60 cells (Bentley and Groudine 1986). Before differentiation triggered by retinoic acid, HL60 cells exhibit a P1/P2 promoter usage ratio of $1: 10$ and transcription readthrough in nuclear runoff transcription assays. After differentiation, c-myc transcription in HL60 cells shows a block to elongation but a continued predominance of P2-initiated transcription (Bentley and Groudine 1986; C. Spencer, unpubl.). In addition, in the oocyte system, P2-initiated transcripts can either block or read through, as manifest in the presence of both full-length and prematurely terminated transcripts. It is possible, therefore, that transacting regulators could operate at transcription initiation, at the elongation blockage point, or at both, to effect the conditional transcription elongation blockage observed in HL60 cells or the loss of elongation blockage in Burkitt's lymphoma cells.

One hypothesis to explain deregulated expression of c-myc in these cells is that the these cells contain for lack) cellular factors that alter wild-type transcription patterns (Croce et al. 1984). Studies of somatic cell hybrids show that rearranged human IgM sequences and the adjacent translocated c-myc allele are transcribed to high levels in both Burkitt's lymphoma cells and in mouse plasmacytoma/Burkitt's lymphoma cell hybrids (Nishikura et al. 1984). In contrast, both transcription units are repressed in a human lymphoblastoid /Croce et al. 1984) or mouse fibroblast (Nishikura et al. 1984) background. Therefore, an appropriate cellular background may be necessary to activate either the normal or cryptic promoters of the translocated c-myc alleles in Burkitt's lymphoma cells. Although our results are consistent with the importance of cellular background in both promoter usage and the block to transcription elongation in c-myc exon 1, it is also possible that cis effects conferred by immunoglobulin sequences adjacent to the translocated c-myc allele, but not included in cloned alleles used in these studies, could contribute to promoter shifts and/or readthrough transcription seen in Burkitt's lymphoma cells.

In summary, these and previous data suggest that at least three mechanisms regulate the block to transcription elongation in normal and Burkitt's lymphoma cells. First, because the block to transcription elongation is conditional in the absence of a promoter switch in HL60 cells, trans-acting factors may modulate transcription elongation blockage at the 3 ' end of exon 1 . Such factors would affect only P2-initiated transcripts, perhaps as part of a transcription initiation complex or by interacting with DNA or RNA sequences near the site of blockage. Second, the predominant and constitutive use of the P1 promoter in Burkitt's lymphoma cells may result in higher than normal levels of c-myc mRNA, as Pl-initiated transcripts are not subject to control via transcription elongation blockage at the $3^{\prime}$ end of exon 1. Third, we predict that in some Burkitt's lymphomas, mutations or deletions within specific subsets of the 95-bp region, which may act as termination signals near the 3 ' end of exon 1, would abolish transcription elongation blockage regardless of promoter use or the presence of trans-acting factors that may normally control blockage. In these cases, readthrough transcription would occur even when transcription initiates from the P2 promoter.

\section{Materials and methods}

Cell lines, DNA clones, and transfections

Mouse pre-B lymphocyte cell line 18-81 was obtained from Dr. K. Marcu, and maintained in RPMI 1640 supplemented with $10 \%$ fetal calf serum, $2 \mathrm{~mm}$ glutamine, and $50 \mu \mathrm{m} \beta$-mercaptoethanol. Samples of the human promyelocytic leukemia cell line, HL60, were obtained from Dr. Steve Collins. Cell lines $\mathrm{BN}, \mathrm{BT}$, and BL were maintained as above with $15 \%$ fetal calf serum (LeStrange 1988). The KK124 cell line and translocated c-myc allele cloned from it were obtained from Dr. I. Kirsch (Denny et al. 1985). AW Ramos, KK124, and EBV-immortalized PBL lines (Cesarman et al. 1987) were maintained in RPMI 1640 with $10 \%$ calf serum, as described above. For sources and descriptions of c-myc DNA clones, see Table 1. Plasmid pmyc4.1HE was obtained from Dr. C. Croce (ar-Rushdi et al. 1983).

Transfections of 18-81 cells were performed by electroporation with an ISCO model 494 power supply and homemade electroporation apparatus and cuvettes (Potter et al. 1986; Toneguzzo et al. 1986). Cells $\left(10^{7}\right.$ to $\left.2 \times 10^{7}\right)$ in PBS were electroporated in the presence of $20 \mu \mathrm{g}$ of linearized human c-myc plasmid plus $5 \mu \mathrm{g}$ of linearized pRSV-neo (Gorman et al. 1983). Stably transfected polyclonal lines were established by selection in $1 \mathrm{mg} / \mathrm{ml} \mathrm{G418} \mathrm{for} \mathrm{2-4} \mathrm{weeks.} \mathrm{Southern} \mathrm{analysis} \mathrm{con-}$ firmed the presence of unrearranged c-myc inserts (from 1 to 10 copies per cell line). Monoclonal cell lines were established from polyclonal populations by dilution plating.

\section{RNA extractions and analyses}

Total cellular RNA was prepared from cell lines and tumor tissues by the guanadinium isothiocyanate method, followed 
by centrifugation through $\mathrm{CsCl}$ (Challoner et al. 1989; LeStrange 1988). Poly $(A)^{+}$RNA was batch-selected with oligo/dT)-cellulose (Collaborative Research) (Challoner et al. 1989).

The [32P]UTP-labeled RNase protection probe was synthesized from a template that contained the 862 -bp PvuII fragment of wild-type human c-myc from -351 to +511 relative to the P1 promoter, cloned into the Bluescribe (Stratagene Cloning Systems)-derived vector PVZ1, which was kindly supplied by Dr. S. Henikoff. RNA was analyzed by RNase protection (U. Novak et al., in prep.). Up to $70 \mu \mathrm{g}$ of total RNA, or $20 \mu \mathrm{g}$ of poly $(\mathrm{A})^{+}$RNA, was mixed with $2.5 \times 10^{5}$ to $5.0 \times 10^{5} \mathrm{cpm}$ of RNA probe and brought to a final volume of $50 \mu$ l plus $80 \%$ formamide, $450 \mathrm{~mm} \mathrm{NaCl}, 10 \mathrm{mM}$ PIPES (pH 6.5), and $1 \mathrm{~mm}$ EDTA. Hybridizations were carried out at $65^{\circ} \mathrm{C}$ for $10 \mathrm{~min}$ and at $42^{\circ} \mathrm{C}$ overnight. RNase digestion buffer [400 $\mu \mathrm{l}$ of $300 \mathrm{~mm}$ $\mathrm{NaCl}, 3 \mathrm{~mm}$ EDTA, $10 \mathrm{~mm}$ Tris (pH 7.4), $10 \mu \mathrm{g} / \mathrm{ml}$ RNase A] was added, and the samples were digested for $30 \mathrm{~min}$ at room temperature. Reactions were stopped with phenol/chloroform and the products were ethanol-precipitated and analyzed on $8 \%$ acrylamide gels $/ 7 \mathrm{M}$ urea.

The $5^{t}$-end-labeled, single-stranded S1 nuclease probes were prepared by annealing either a kinased-treated antisense 26base oligonucleotide, homologous to a region of human c-myc, 53-79 bases 3' to the P2 promoter (Figs. 5 and 7), or a kinasetreated antisense 90-base oligonucleotide, homologous to a region of human c-myc, $180-270$ bases $3^{\prime}$ to the P2 promoter (Fig. 8 ), to single-stranded Ml3 c-myc templates and extending with Klenow and dNTPs. The double-stranded M13 was then cut with SmaI, and the single-stranded end-labeled fragment isolated and eluted from a $5 \%$ acrylamide $/ 7 \mathrm{M}$ urea gel. Total RNA (from 5 to $40 \mu \mathrm{g}$ ) from cell lines or Xenopus oocytes was hybridized to $10,000 \mathrm{cpm}$ of purified probe, in $10 \mu \mathrm{l}$ of $80 \%$ formamide, $500 \mathrm{mM} \mathrm{NaCl}, 20 \mathrm{mM}$ PIPES (pH 7.0), and $1 \mathrm{mM}$ EDTA, at $95^{\circ} \mathrm{C}$ for $5 \mathrm{~min}$ and at $58^{\circ} \mathrm{C}$ overnight. Digestion was performed by adding $100 \mu \mathrm{l}$ of $300 \mathrm{~mm} \mathrm{NaCl}, 30 \mathrm{~mm}$ sodium acetate $(\mathrm{pH} 5.5), 1 \mathrm{~mm}$ zinc sulfate, and $250 \mathrm{U} / \mathrm{ml}$ of S1 nuclease, and incubating at $37^{\circ} \mathrm{C}$ for $40 \mathrm{~min}$. Products were ethanol-precipitated and analyzed on $6 \%$ acrylamide $/ 7 \mathrm{M}$ urea gels.

The Sl probe in Figure 8 contains a 31 -base deletion and is homologous to $\triangle \mathrm{P} 2$ RNA. P1 transcripts synthesized from wild-type and $\triangle$ P2TATA templates would loop out over the deletion point in the DNA probe, but continuously protect the DNA probe through this region. This probe protects a fragment of 401 bases, corresponding to transcripts initiated at the P1 promoter and 270 bases, corresponding to transcripts initiating at the $\mathrm{P} 2$ promoter.

Northern blot analyses of cell line RNAs in Figure 2 were performed as described (LeStrange 1988). Probes were a ${ }^{32} \mathrm{P}-\mathrm{la}$ beled 1.3-kb ClaI-EcoRl fragment containing human c-myc exon 3 sequences and a 1.8 -kb $\beta$-actin cDNA fragment (LeStrange 1988).

\section{Nuclear runoff transcription assays}

Isolation of nuclei from cell lines and nuclear runoff assays were performed as described (Bentley and Groudine 1986). Runoff transcription products were purified and hybridized to excess sense and antisense single-stranded probes slot-blotted onto GeneScreen Plus filters. Single-stranded probes contain sequences of human and murine c-myc and Xenopus $5 \mathrm{~S}$ genes. Double-stranded plasmid probes contained fragments of chicken histone H2b and chicken GAPDH /Challoner et al. 1989). Filters were washed as described (Bentley and Groudine $1986)$, with the addition of an RNase A wash $(2 \mu \mathrm{g} / \mathrm{ml}$ RNase $A$ in $2 \times$ SSC for $30 \mathrm{~min}$ at room temperature). Filters were ex- posed to Kodak XAR-5 film for 1-4 days using an intensifying screen.

The single-stranded M13 probes for human c-myc regions were sense and antisense strands of $(1) 5^{\prime}$, a 568 -base NsiI-SmaI fragment extending from -672 to -104 upstream of the human c-myc P1 promoter; (2) exon 1, a 445-base XhoI-PvuII fragment extending from +66 to +511 ; (3) intron $1-5$ ', a 425base Pvull-SstI fragment extending from +511 to $+936_{;}$(4) intron $1-3$ ', a 606-base Sst I fragment extending from +936 to +1542 ; and (5) exon 2, a 414-base PstI fragment extending from +2310 to +2724 . Uridine contents of sense transcripts in these regions are noted in the figure legends.

The single-stranded probes for mouse c-myc regions were sense and antisense strands of: (1) $5^{\prime}$, a 391-base PvuII fragment extending from -368 to +23 relative to the mouse c-myc P1 promoter; (2) exon 1, a 436-base HindIII-BgIII fragment extending from +140 to $+576_{;}$( 3 ) intron 1, an 816-base BglII-SstI fragment extending from +700 to +1516 . These fragments were cloned into the Bluescribe-derived (Stratagene Cloning Systems/ vector $\mathrm{pVZ1}$, which was obtained from Dr. S. Henikoff. Single-stranded probes were obtained by coinfection with helper phage (Vieira and Messing 1987).

\section{Construction of deletion mutants}

The promoter deletion plasmids were constructed by in vitro mutagenesis of the full-length wild-type human c-myc allele. This wild-type allele was subcloned from plasmid pmyc4.1HE (ar-Rushdi et al. 1983) into the pVZ1 vector to create the parent construct pBS2. Single-stranded phage DNA was obtained by coinfecting pBS2 with helper phage M13K07 /Vieira and Messing 1987), and the single-stranded DNA was used as a template for in vitro mutagenesis.

The $\Delta \mathrm{Pl}$ construct was created by annealing a 40 -base synthetic oligonucleotide, spanning the region 20 bases upstream of the P1 promoter TATA box and 20 bases downstream of the P1 cap site, to the single-stranded pBS2 DNA. This resulted in a 29 -base loop out of $\mathrm{pBS} 2$, from -27 to +1 relative to the $\mathrm{Pl}$ promoter, and, hence, deletion of the region from the P1 TATA box to cap site, on the newly synthesized single strand. The oligonucleotide was extended with Klenow in the presence of dNTPs and ligated by T4 DNA ligase. The resulting doublestranded template was transformed into XL-1 Blue competent cells (Stratagene Cloning Systems), ampicillin-resistant transformants were selected, and deletions were verified by DNA sequencing. The $\triangle$ P1TATA construct, which contains a deletion of the P1 TATA box from -27 to -21 , was synthesized by the same methodology. The $\Delta \mathrm{P} 2$ construct was created by annealing a 40-base synthetic oligonucleotide, spanning a region 20 bases upstream of the P2 promoter TATA box and 20 bases downstream of the P2 cap site, to single-stranded pBS2 DNA. Annealing of this oligonucleotide results in a 31-base loop out in $\mathrm{pBS} 2$, from -30 to +1 relative to the $\mathrm{P} 2$ promoter, and, hence, deletion of the region betweeen the P2 TATA box to cap site on the newly synthesized single strand. Extension, ligation, and analysis was as for $\triangle \mathrm{Pl}$. The $\triangle \mathrm{P} 2 \mathrm{TATA}$ construct, which contains a deletion of the P2 TATA box, from -30 to -24 relative to the $\mathrm{P} 2$ promoter, was also synthesized by this method.

\section{Oocyte injections and RNA analysis}

Xenopus oocyte germinal vesicles were injected with full-length, wild-type, in-vitro-mutagenized, and Burkitt's lymphoma-cloned c-myc alleles, as described (Bentley and Groudine 1988). RNA was extracted from 
oocytes and analyzed by Northern blot. The probe was a ${ }^{32} \mathrm{P}-$ labeled $1.3-\mathrm{kb}$ NaeI fragment extending from position +208 in exon 1 to +1557 in intron 1 .

\section{Acknowledgments}

We are very grateful to Linnea Brody and Mary Peretz for excellent technical assistance. We thank Hazel Sive, Andrew Lassar, Hal Weintraub, and Bob Eisenman for discussion and critical reading of the manuscript, all members of the Groudine laboratory for discussion and reagents, and Riccardo Dalla-Favera and Bayard Clarkson for cell lines and RNA samples. This work was supported by a Fellowship Award from the Alberta Heritage Foundation for Medical Research to C.S., National Science Foundation grant DCB-8802490 and National Institute Health grant AI-27291 to M.G., and U.S. Public Health Service grant CA-16599 to W.H.

\section{References}

ar-Rushdi, A., K. Nishikura, J. Erikson, R. Watt, G. Rovera, and C. Croce. 1983. Differential expression of the translocated and untranslocated c-myc oncogene in Burkitt lymphoma. Science 222: 390-393.

Barik, S., B. Ghash, W. Whalen, D. Lazinski, and A. Das. 1987. An antitermination protein engages the elongating transcription apparatus at a promoter-proximal recognition site. Cell 50: 885-899.

Bentley, D.L. and M. Groudine. 1986. A block to elongation is largely responsible for decreased transcription of c-myc in differentiated HL60 cells. Nature 321: 702-706.

1988. Sequence requirements for premature termination of transcription in the human c-myc gene. Cell 53: $245-256$.

Blanchard, J.-M., M. Piechaczyk, C. Dani, J.C. Chambard, A. Franchi, J. Pouyssegur, and P. Jeantuer. 1985. c-myc gene is transcribed at high rate in $\mathrm{G}_{0}$-arrested fibroblasts and is post-transcriptionally regulated in response to growth factors. Nature 317: 443-445.

Cesarman, E., R. Dalla-Favera, D. Bentley, and M. Groudine. 1987. Mutations in the first exon are associated with altered transcription of c-myc in Burkitt lymphoma. Science 238: $1272-1275$.

Challoner, P., S. Moss, and M. Groudine. 1989. Expression of replication-dependent histone genes in avian spermatids involves an alternate pathway of mRNA 3 '-end formation. Mol. Cell. Biol. 9: 902-913.

Cole, M. 1986. The myc oncogene: Its role in transformation and differentiation. Annu. Rev. Genet. 20: 361-384.

Croce, C.M., J. Erikson, A. ar-Rushdi, D. Aden, and K. Nishikura. 1984. Translocated c-myc oncogene of Burkitt's lymphoma is transcribed in plasma cells and repressed in lymphoblastoid cells. Proc. Natl. Acad. Sci. 81: 3170-3174.

Denny, C.T., G.F. Hollis, I.T. Magrath, and I. Kirsch. 1985. Burkitt lymphoma cell line carrying a variant translocation creates new DNA at the breakpoint and violates the hierarchy of immunoglobulin gene rearrangement. Mol. Cell. Biol. 5: 3199-3207.

Dmitrovsky, E., W.M. Kuehl, G.F. Hollis, I.R. Kirsch, T.P. Bender, and S. Segal. 1986. Expression of a transfected human c-myc oncogene inhibits differentiation of a mouse erythroleukaemia cell line. Nature 322: 748-750.

Eick, D. and G.W. Bornkamm. 1986. Transcriptional arrest within the first exon is a fast control mechanism in c-myc gene expression. Nucleic Acids Res. 14: 8331-8346.

Eick, D., R. Berger, A. Polack, and G.W. Bornkamm. 1987.
Transcription of c-myc in human mononuclear cells is regulated by an elongation block. Oncogene 2: 61-65.

Eick, D. and G.W. Bornkamm. 1989. Expression of normal and translocated c-myc alleles in Burkitt's lymphoma cells: evidence for different regulation. EMBO J. 8: 1965-1972.

Eick, D., A. Polack, E. Kofler, and G.W. Bornkamm. 1988. The block of elongation in c-myc exon 1 is abolished in Burkitt's lymphoma cell lines with variant translocations. Oncogene 3: $397-403$.

Freytag, S.O. 1988. Enforced expression of the c-myc oncogene inhibits cell differentiation by precluding entry into a distinct predifferentiation state in G0/G1. Mol. Cell. Biol. 8: $1614-1624$

Gazin, C., S. Dupont de Dinechin, A. Hampe, J.-M. Masson, P. Martin, D. Stehelin, and F. Galibert. 1984. Nucleotide sequence of the human c-myc locus; provocative open reading frame within the first exon. EMBO /. 3: 383-387.

Gorman, C., R. Padmanabhan, and B. Howard. 1983. High efficiency DNA-mediated transformation of primate cells. Science 221: $551-553$.

Grayhack, E.J., X. Yang, L.F. Lau, and J.W. Roberts. 1985. Phage lambda gene $Q$ antiterminator recognizes RNA polymerase near the promoter and accelerates it through a pause site. Cell 42: 259-269.

Hann, S.R., M.W. King, D.L. Bentley, C.W. Anderson, and R.N. Eisenman. 1988. A nonAUG translational initiation in c-myc exon 1 generates an $\mathrm{N}$-terminally distinct protein whose synthesis is disrupted in Burkitt's lymphoma. Cell 52: 185-195.

Hernandez, N. and R. Lucito. 1988. Elements required for transcription initiation of the human U2 snRNA gene coincide with elements required for snRNA 3 ' end formation. EMBO I. 7: 3125-3134.

Holt, J.T., R.L. Redner, and A.W. Nienhuis. 1988. An oligomer complementary to cmyc mRNA inhibits proliferation of HL60 cells and induces differentiation. Mol. Cell. Biol. 8: $963-973$.

Horwitz, R.J., J. Li, and J. Greenblatt. 1987. An elongation control particle containing the $\mathrm{N}$ gene transcriptional antitermination protein of bacteriophage lambda. Cell 51: 631641.

Lacy, J., S.N. Sarkar, and W.C. Summers. 1986. Induction of c-myc expression in human B-lymphocytes by B-cell growth factor and anti-immunoglobulin. Proc. Natl. Acad. Sci. 83: $1458-1462$.

LeStrange, R.C. 1988. Molecular analysis of the $8 ; 14$ translocation in Burkitt's lymphoma and associated changes in the c-myc gene. Ph.D. Thesis, Cornell University.

Lindsten, T., C.H. June, and C. Thompson. 1988. Multiple mechanisms regulate $\mathrm{c}-\mathrm{myc}$ gene expression during normal T cell activation. $E M B O$ I. 7:2787-2794.

Mechti, N., M. Piechaczyk, J.-M. Blanchard, L. Marty, A. Bonnieu, Ph. Peanteur, and B. Lebleu. 1986. Transcriptional and post-transcriptional regulation of $\mathrm{c}$-myc expression during the differentiation of murine erythroleukemia Friend cells. Nucleic Acids Res. 14: 9653-9666.

Nepveu, A. and K.B. Marcu. 1986. Intragenic pausing and antisense transcription within the murine c-myc locus. EMBO $/$. 5: 2859-2865.

Nepveu, A., K.B. Marcu, A.I. Skoultchi, and H. Lachman. 1987. Contributions of transcriptional and post-transcriptional mechanisms to the regulation of c-myc expression in mouse erythroleukemia cells. Genes Dev. 1: 938-945.

Neuman de Vegvar, H.E., E. Lund, and J.E. Dahlberg. 1986. 3 'end formation of U1 snRNA precursors is coupled to transcription from snRNA promoters. Cell 47: 259-266. 
Nishikura, K., A. ar-Rushdi, J. Erikson, E. DeJesus, D. Dugan, and C.M. Croce. 1984. Repression of rearranged gene and translocated c-myc in mouse $3 \mathrm{~T} 3$ cells $\times$ Burkitt lymphoma cell hybrids. Science 224: 399-402.

224: $399-402$.

Nishikura, K., S. Goldflam, and G.A. Vuocolo. 1985. Accurate and efficient transcription of human c-myc genes injected into Xenopus laevis oocytes. Mol. Cell. Biol. 5: 1434-1441.

Nishikura, K. and J.M. Murray. 1988. The mechanism of inactivation of the normal c-myc gene locus in human Burkitt's lymphoma cells. Oncogene 2: 493-498.

Novak, U., E. Harris, W. Forrester, M. Groudine, and R. Gelinas. 1990. Elevated $\beta$-globin expression after retroviral transfer of locus activation region human beta-globin gene derivatives into murine erythroleukemia cells. (submitted).

Pelicci, P-G., D.M. Knowles, I. Magrath, and R. Dalla-Favera. 1986. Chromosomal breakpoints and structural alterations of the c-myc locus differ in endemic and sporadic forms of Burkitt lymphoma. Proc. Natl. Acad. Sci. 83: 2984-2988.

Piechaczyk, M., J.-Q. Yang, J.-M. Blanchard, P. Jeanteur, and K.B. Marcu. 1985. Posttranscriptional mechanisms are responsible for accumulation of truncated c-myc RNA's in murine plasma cell tumors. Cell 42: 589-597.

Potter, H., L. Weir, and P. Leder. 1986. Enhancer-dependent expression of human $\mathrm{K}$ immunoglobulin genes introduced into mouse pre-B lymphocytes by electroporation. Proc. Natl. Acad. Sci. 81: 7161-7165.

Rabbitts, T.H., A. Forster, P. Hamlyn, and R. Baer. 1984. Effect of somatic mutation within translocated c-myc genes in Burkitt's lymphoma. Nature 309: 592-597.

Schweinfest, C.F., S. Fukiwara, L. Lau, and T.S. Papas. 1988. c-myc can induce expression of $\mathrm{G} 0 / \mathrm{G} 1$ transition genes. Mol. Cell. Biol. 8: 3080-3087.

Siebenlist, U., L. Hennighausen, J. Battey, and P. Leder. 1984. Chromatin structure and protein binding in the putative regulatory region of the c-myc gene in Burkitt lymphoma. Cell 37: 381-391.

Taub, R., C. Moulding, I. Battey, W. Murphy, T. Vasicek, G.M. Lenoir, and P. Leder. 1984a. Activation and somatic mutation of the translocated c-myc gene in Burkitt lymphoma cells. Cell 36: 339-348.

Taub, R., K. Kelly, J. Battey, S. Latt, G.M. Lenoir, U. Tantravahi, Z. Tu, and P. Leder. 1984b. A novel alteration in the structure of an activated c-myc gene in a variant $t(2 ; 8)$ Burkitt lymphoma. Cell 37: 511-520.

Toneguzzo. F., A. Hayday, and A. Keating. 1986. Electric fieldmediated DNA transfer: transient and stable gene expression in human and mouse lymphoid cells. Mol. Cell. Biol. 6: 703-706

Vieira, J. and I. Messing. 1987. Production of single-stranded plasmid DNA. Methods Enzymol. 153: 3-11.

Wiman, K.G., B. Clarkson, A.C. Hayday, H. Saito, S. Tonegawa, and W.S. Hayward. 1984. Activation of a translocated c-myc gene: Role of structural alterations in the upstream region. Proc. Natl. Acad. Sci. 81: 6798-6802.

Wright, S. and M. Bishop. 1989. DNA sequences that mediate attenuation of transcription from the mouse protooncogene c-myc. Proc. Natl. Acad. Sci. 86: 505-509.

Yang,J., S.R. Bauer, J.F. Muchinski, and K.B. Marcu. 1985. Chromosome translocations clustered $5^{\prime}$ of the murine c-myc gene qualitatively affect promoter usage: Implications for the site of normal c-myc regulation. EMBO J. 4: 1441-1447.

Yokoyama, K. and F. Imamoto. 1987. Transcriptional control of the endogenous myc protooncogene by antisense RNA. Proc. Natl. Acad. Sci. 84: 7363-7367.

Zajac-Kaye, M., E.P. Gelmann, and D. Levens. 1988. A point mutation in the c-myc locus of a Burkitt's lymphoma abolishes binding of a nuclear factor. Science 240: 1776-1779. 


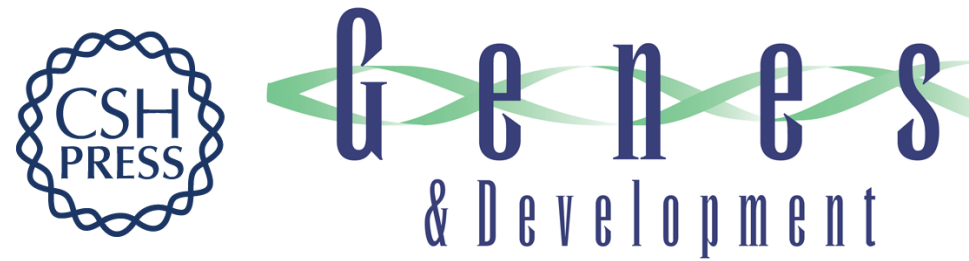

\section{The block to transcription elongation is promoter dependent in normal and Burkitt's lymphoma c-myc alleles.}

C A Spencer, R C LeStrange, U Novak, et al.

Genes Dev. 1990, 4:

Access the most recent version at doi:10.1101/gad.4.1.75

References This article cites 47 articles, 19 of which can be accessed free at:

http://genesdev.cshlp.org/content/4/1/75.full.html\#ref-list-1

License

Email Alerting

Service

Receive free email alerts when new articles cite this article - sign up in the box at the top right corner of the article or click here.

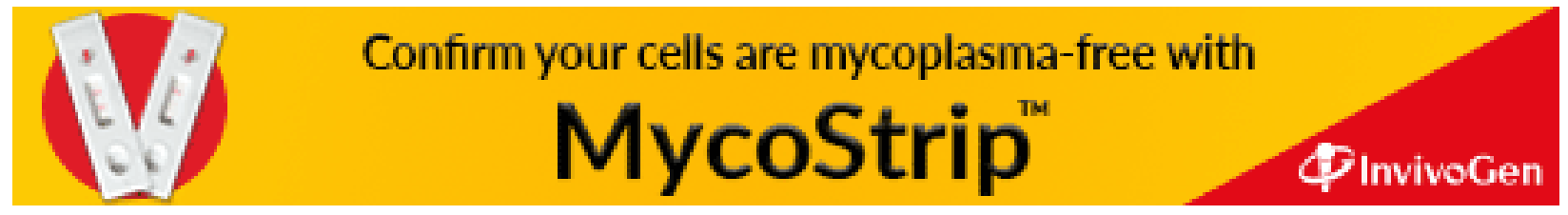

